Journal

of Geography,

Politics and Society

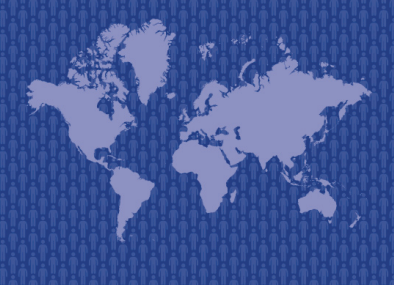

$10(1) / 2020$

\section{Journal of Geography, Politics and Society}

2020, 10(1), 23-32

https://doi.org/10.26881/jpgs.2020.1.04

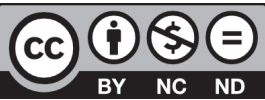

\title{
DEMOGRAPHIC ASPECTS OF THE DEVELOPMENT OF THE GERMAN STATE MECKLENBURG-VORPOMMERN
}

\author{
Iwona Jażewicz \\ Institute of Social and Economic Geography and Tourism, Pomeranian University in Słupsk, Arciszewskiego 22, 76-200 Slupsk, Poland, ORCID: 0000-0002-5698- \\ $442 \mathrm{X}$ \\ e-mail: iwona.jazewicz@apsl.edu.pl
}

\section{Citation}

Jażewicz I., 2020, Demographic aspects the development of the German state Mecklenburg- Vorpommern, Journal of Geography, Politics and Society, 10(1), 23-32.

\begin{abstract}
This publication presents selected aspects of the demographic development of East Germany based on the example of the state of Mecklenburg-Vorpommern, which after the reunification of Germany in 1990 found itself in a new socio-economic situation. The main goal of the study was to recognize the mechanisms, regularities and directions of changes in the population, to identify the determinants and consequences of changes in terms of reproductive behaviors, and to identify new migratory behaviors of the society. The conducted research showed that the demographic situation of the borderland of state of Mecklenburg-Vorpommern radically changed after the reunification of Germany. At that time, the processes described in the theory of the second demographic transition began. In particular, they concerned a slump in the number of births and a decrease in female fertility, while mortality remained at the same level. In addition, emigration to the neighboring old federal states of Germany in search of better living and working conditions deepened the depopulation processes, led to deformation of demographic structures and, consequently, to the progressive process of demographic aging. Some alleviation of the demographic situation occurred as a result of the inflow of Asian and African immigrants of a relatively young age structure and high biological resilience.
\end{abstract}

\section{Key words}

population, birth rate, migrations, real growth, Mecklenburg-Vorpommern

Received: 18 November 2019

Accepted: 10 March 2020

Published: 31 March 2020

\section{Introduction}

In research of regional systems, it is extremely important to recognize demographic structures and processes. In the subjective concept of the region, Z. Chojnicki (1999) points to three simple components of the region, i.e. composition, environment and structure. This study will focus on discussing the composition of the region understood as a population in a demographic aspect and living in a specific territory. It should be noted that in a stable political and economic situation of regions demographic changes are usually subject to relatively high inertia. Demographic phenomena and processes in regions affected by geopolitical factors are shaped slightly differently. A good example in Europe was the 
geopolitical division of Germany into the western part territorially belonging to the Federal Republic of Germany and the eastern part belonging to the German Democratic Republic. The division of Germany, which lasted for 45 years until 1990, resulted in a diversified demographic situation of both parts of the German state. When Western Germany, or more broadly Western Europe, was affected by the consequences of the second demographic transition triggered by the modernization of societies, in Eastern Germany and Eastern Europe they were restrained and deformed (Okólski, 2010).

It was not until the collapse of the system of communist states that the processes related to the theory of the second of demographic transition began to take place rapidly in them. This concerns changes in terms of marriage and parity (cf. Basten et al., 2013; Magdalenić, 2016; Kurek, 2012; Osiewalska, 2018), and to a lesser extent changes in mortality (Michalski, 2012; Šprocha et al., 2015) and migration (cf. van Nimwegen, van der Erf, 2010; S. Akturk, 2016).

In view of the outlined issues, the aim of this publication is to identify demographic processes in East Germany based on the example of the state of Mecklenburg-Vorpommern after the integration of the German state in 1990. Changes in population and in the distribution of the population were analyzed; the consequences of changes in demographic structures were also indicated, and an attempt was made to answer to the following research questions: Did changes in reproductiveness occur? What does fertility look like? What are the correlations between the birth rate and the death rate? What is the role of migration in balancing reproduction of the population?

\section{Data and methods}

The research concerned the state of MecklenburgVorpommern in Germany divided into 6 districts (Ger. Landkreis) and 2 independent urban districts (Ger. Kreisfreie Stadt). The research methodology was secondary to the established research objectives and was modified by the availability of source materials. The basic source material was based on data from the Statistisches Amt Mecklenburg-Vorpommern (www.statistik-mv.de) [Statistical Office of Mecklenburg-Vorpommern] and the publications Statistische Jahrbücher [Statistical Yearbooks] and Statistische Berichte [Statistical Reports]. To show Mecklenburg-Vorpommern in comparison to the whole country, the Satistisches Bundesamt [Federal Statistical Office] database (www.destatis.de) was used. The temporal scope of the study covered
1990-2018, i.e. the period of socio-economic changes in East Germany.

To prepare this study, research on theoretical and methodological issues concerning one of the most important problems in modern Europe - demographic challenges - was used. An attempt was made to explain the diversity of population processes in relation to the theory of the second demographic transition using works of D.J. Van de Kaa (1987), R. Lesthaeghe $(2010,2014)$, J. Bogaarts and T. Sobotka (2012) and J.R. Goldstein et al. (2009). To resolve the main problem of this publication, studies on demographic problems in East Germany were used (Buchman, 2009; Grundmann, 1998; Jażewicz, 2008; Jezierska-Thöle, 2016; Milewski, 2010; Pastusz$\mathrm{ka}, 2019)$ and works presenting the determinants and consequences of population changes in the studied area (Ciok et al., 2008; Grykień, 2004; Jezierska-Thöle, 2018; Pastuszka, 2016).

\section{Dynamics of population changes and disparities in its distribution}

In 2018, 1.6 million people lived in MecklenburgVorpommern, which represented $1.9 \%$ of the total population of Germany. The population development can be divided into two sub-periods. One covers the period of 1990-2013, when the population showed systematic downward trends, decreasing by almost $1 / 5$. The second period occurred in 2014-2018, when the number of inhabitants began to increase due to foreign immigration. In terms of population, Mecklenburg-Vorpommern was 14th out of 16 German states. The land area is $23,293 \mathrm{~km}^{2}$, which places it 6 th in terms of area in the country. The relatively large area with a low population places Mecklenburg-Vorpommern among states with the lowest population density of 69 persons $/ \mathrm{km}^{2}$, with the average for Germany equal to 232 persons $/ \mathrm{km}^{2}$ (Fig. 1).

However, considering the intra-regional population, where a district remains the basic unit of division, some intra-regional disparities emerge. Among 8 districts, the most numerous groups were those with the regressive type of population changes (loss above 5\%) (Fig. 2).

Units located in the border zone with Poland are the districts with the largest depopulation characteristics. It should be noted that the situation of border areas is always worse compared to areas further inland. This is due to their location outside the zone of influence of urban-industrial centers, and development impulses arrive with a long delay (Ciok et al., 2008). Additionally, in the past, these districts were 


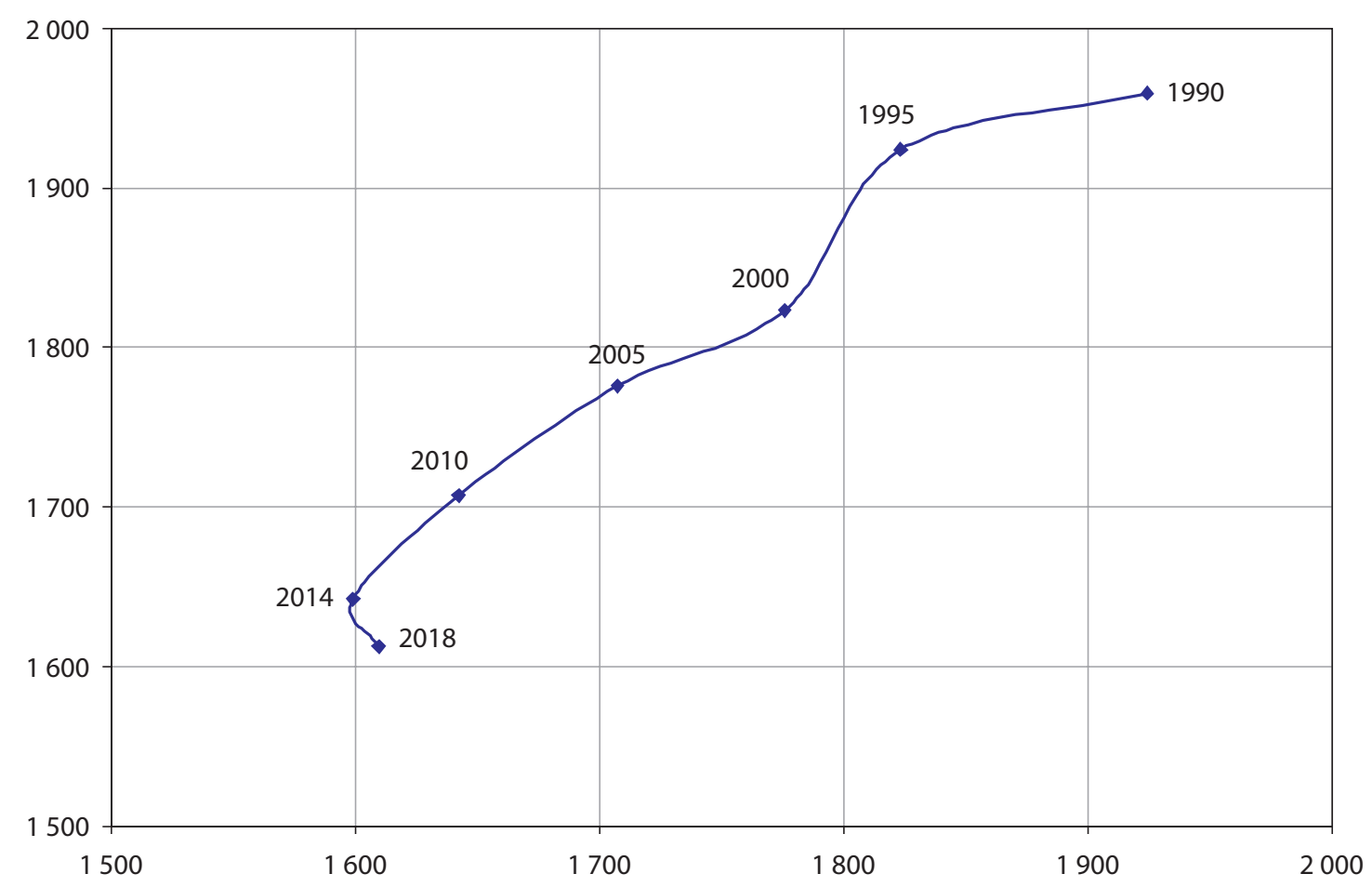

Fig. 1. Trajectory of the population development [in thousands] of the state of Mecklenburg-Vorpommern Source: Own study based on www.statistik-mv.de

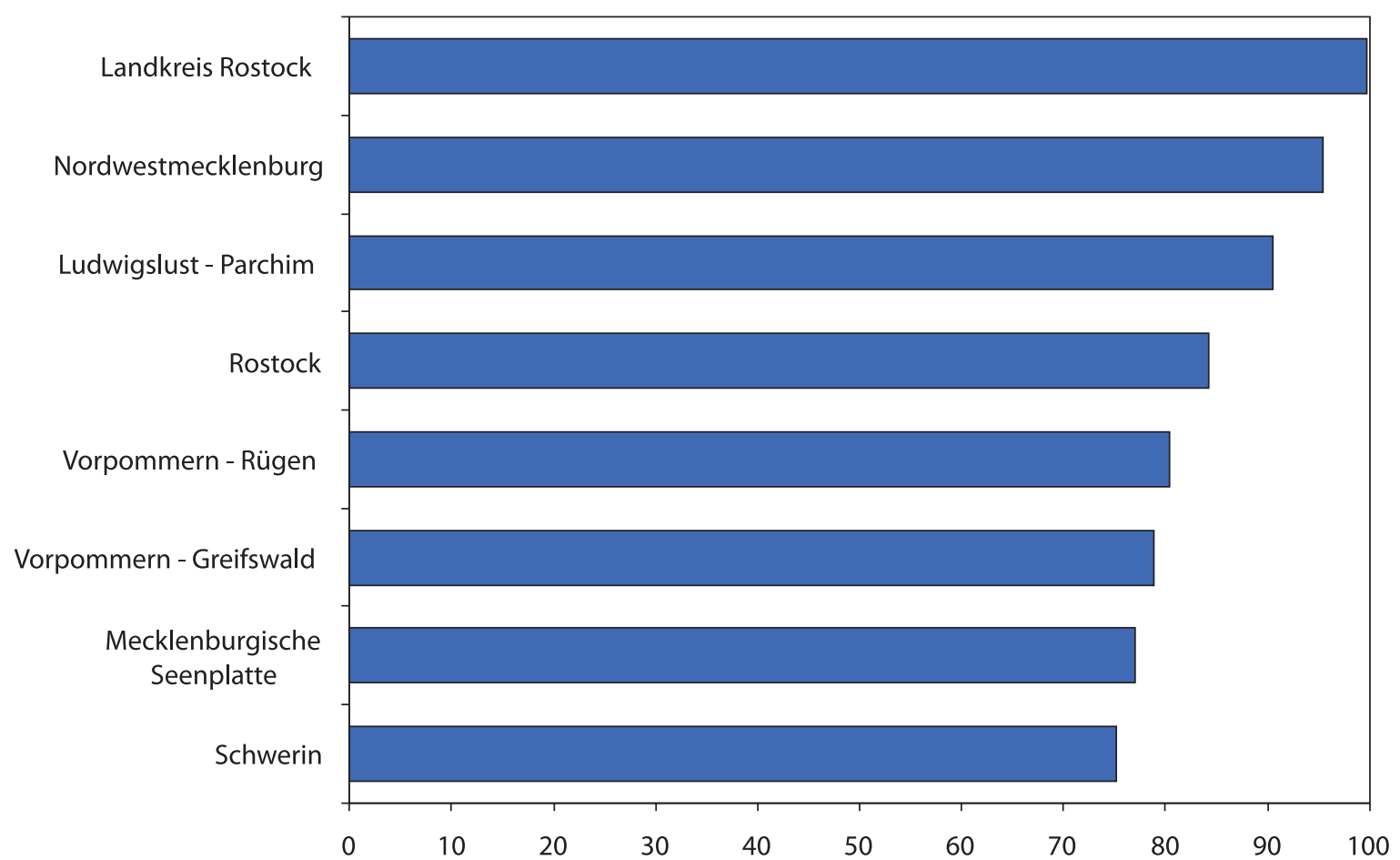

Fig. 2. Population dynamics of districts in the federal state of Mecklenburg-Vorpommern in 1990-2018 (1990=100\%) Source: Own study based on www.statistik-mv.de

connected with cooperative agriculture. $95.4 \%$ of arable land in Mecklenburg-Vorpommern remained under the control of the state sector. The unification of Germany caused transformation of agriculture in the new federal states, as a result of which rural residents suffered high social costs, because approx. $88 \%$ of those employed in the agricultural sector lost their jobs (Grykień, 2004). Simultaneously, the loss of subsistence primarily by small towns with a single specialized industrial function contributed to the 
collapse of their economic base and, consequently, to the loss of jobs. As a result, the rural labor market collapsed and a surplus workforce was released. Employees of state-owned production cooperatives were dismissed and, being accustomed to social assistance in the former GDR, they were unable to pull themselves together in the new situation based on the mechanisms of free competition of German economy (Pastuszak, 2016). Consequently, they became part of the resource of the unemployed. In the initial period of transformation, i.e. in 1994, the unemployment rate in Mecklenburg-Vorpommern amounted to $16.2 \%$ and reached its maximum in 2004 when it was equal to $20.4 \%$. According to the research, there were large intraregional disparities as regards the unemployment rate. As expected, it was the highest in the new German federal states, with the highest value recorded in Mecklenburg-Vorpommern. The situation was slightly different in districts located in the impact zone of sub-regional centers, i.e. Rostock or Wismark, as well as the regional center - Schwerin. While population in these cities was decreasing, and their apparent demographic shrinkage was observed, the observed increase in population in the suburban area suggests that the apparent depopulation is closely related to suburbanization because in the areas surrounding the city the population increased. The suburban zones of the cities of Rostock, Wismar and Schwerin quickly lost their agricultural function and became urbanized. Currently, they are characterized by the development of nonagricultural functions.

However, considering the size of the population in the federal state of Mecklenburg-Vorpommern in 2018 in the city-village cross-section, 1.0 million people lived in cities, which constituted $62.5 \%$ of the total population. The urban settlement network consisted of 84 municipal units and was based on a subsystem of 75 small towns, 8 medium towns and one large city (Rostock).

The distribution of the population and the current settlement system of Mecklenburg-Vorpommern largely refers to the conditions of the natural environment. In fact, one can talk about two settlement zones, one related to the southern Baltic zone, with good natural conditions taking into account the values of coastal landscapes, the hydrographic system and building conditions. It is worth noting here that the largest cities, Rostock, Wismar, Greisfwald or Stralsund, are located in this Baltic part of Mecklenburg-Vorpommern. The second settlement zone covers the lake district, which in turn is characterized by young glacial landscapes. The varied configuration of the Mecklenburg Lakeland, a large number of lakes, as well as extensive forest complexes were not conducive to active socio-economic development, and the settlement network is based on the subsystem of small towns.

\section{Parity and mortality}

Shaping the natural increase or loss of population is based on the relationships between the number of births and deaths (Van de Kaa, 1987). This set of two components allows determining the balance of natural movement in the region (Lesthaeghe, 2010, 2014). In turn, the level of births is a resultant of the demographic structure of the population, and above all the number of women in procreative age and the procreative proclivity of society.

Mecklenburg-Vorpommern belongs to regions with unfavorable parity trends. As early as in 1990, Mecklenburg-Vorpommern took the first place among the old and new German states in terms of the parity level, while in 2018 MecklenburgVorpommern occupied the fourteenth place along with Thuringia. A comparison of the distribution of live births per 1000 population using "box-whiskers" clearly shows that it is more favorable for Germany than for Mecklenburg-Vorpommern (Fig. 3).

Research shows that during the period of Wendeknick ${ }^{1}$ changes in the number of births are part of a complex cycle intertwined with the phases of growth and decline. In 1990-1994 the number of births dramatically decreased. That situation result from mass emigration after the unification of Germany, of mainly young people, to the old federal states (Grundmann, 1998). The next wave of an increase in births occurred in the mid-1990s and lasted until 2010. The maximum number of births in this period was recorded in 2010 and amounted to 13,300 births $(8.1 \% 0)$. The next fall in births took place in 2011-2013, and this trend would probably have been perpetuated, had it not been for the inflow of immigrant families since 2014, which caused another wave of increased births (Milewski, 2010). In 2018, every fourth child in Germany was foreignborn, which constituted $24.0 \%$, and the fertility rate among foreigners was 2.122. In the group of foreigners, mothers from Asia ( $26.1 \%$ of all foreign births), Turkey (10.7\%) and Africa (10.6\%) were the most numerous. In Mecklenburg-Vorpommern, in 20142018, the number of children born to immigrant mothers increased from 373 births in 2014 to 1062 births in 2018, and their share increased respectively from $2.9 \%$ in 2014 to $8.1 \%$ in 2018.

\footnotetext{
1 Wendeknick denotes political and economic changes in East Germany after 1990 (Jezierska-Thöle, 2016).
} 


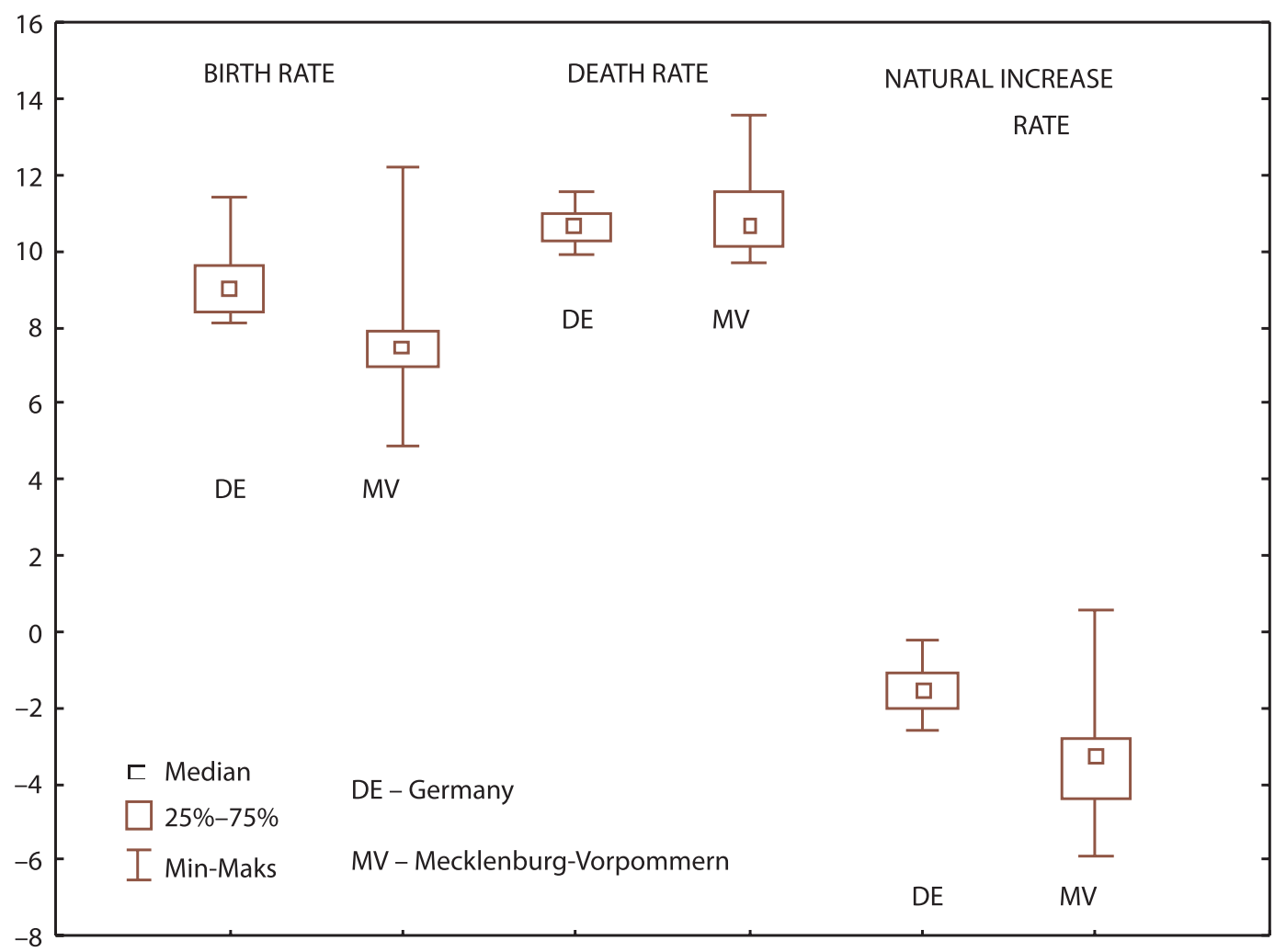

Fig. 3. The average value of natural increase components in 1990-2018 for Mecklenburg-Vorpommern and Germany Source: Own study based on www.destatis.de

Spatially, the birth rate refers to the centrifugal system associated with the proximity of the state border (Fig. 4). The gradient of the mean level of births gradually increased with the distance from the border, and in the district of Ludwigslust-Parchim on the opposite western side, it had the highest values.

The cyclical nature of fluctuations in the level of births depends on the number of women in the age of increased procreation (20-29 years old) and on their fertility. Total female fertility in MecklenburgVorpommern, similarly to the number of births, was drastically falling after the reunification of Germany (Goldstein, Kreyenfeld, 2011). It is enough to mention that in the years 1990-2005 the total fertility rate decreased by more than a half. A slowdown in the downward trend in total female fertility was observed after the accession of Poland and other Central and Eastern European countries to the European Union, the opening of the German labor market in 2011 and a high inflow of immigrants from Asia and Africa (Fig. 5).

As mentioned earlier, the ensuing situation is reflected in an increase in births by demographically more resilient and younger primiparous women, but also in an increase in the number of women in the reproductive age and their biological resilience in younger age brackets (Goldstein et al., 2009). The process looks different if live births per 1000 women at age specified are analyzed with a use of the coefficient of variation $\left(V_{x}\right)$. Variability of live births per 1000 women at age specified in 1990-2018 was quite diverse. The older the women's age group, the higher the value of the coefficient of variation. Thus, the strongest changes in 1990-2018 concerned the subpopulation of women aged $40-44\left(\mathrm{~V}_{\mathrm{x}}-56.3 \%\right)$ and 35-39 years old $\left(V_{x}-49.3 \%\right)$; a relatively stable situation was in the age group 25-29 ( $\left.\mathrm{V}_{\mathrm{x}}-14.7 \%\right)$. The total fertility rate, i.e. the sum of live births per 1000 women at age specified, is a synthetic measure of total female fertility. Its value in MecklenburgVorpommern was similar to the trends of changes in the live births rate and the fertility rate. In fact, from the reunification of Germany till the accession of the countries of Central and Eastern Europe to the European Union, this was a downward trend (from 1.61 in 1990 to 1.342 in 2004), while in 2005-2018 due to foreign immigration there was a marked a upward trend (up to 1.550 in 2018) (Bogaarts, Sobotka, 2012).

Deaths constitute the second component of the natural movement of population. In examining the diversity of the population living in MecklenburgVorpommern, the features that make up the mortality pattern were used. The absolute death rate in Mecklenburg-Vorpommern in past three decades fluctuated between 17,000 and 22,000 deaths per year, and the death rate ranged from $9.8 \%$ o in 


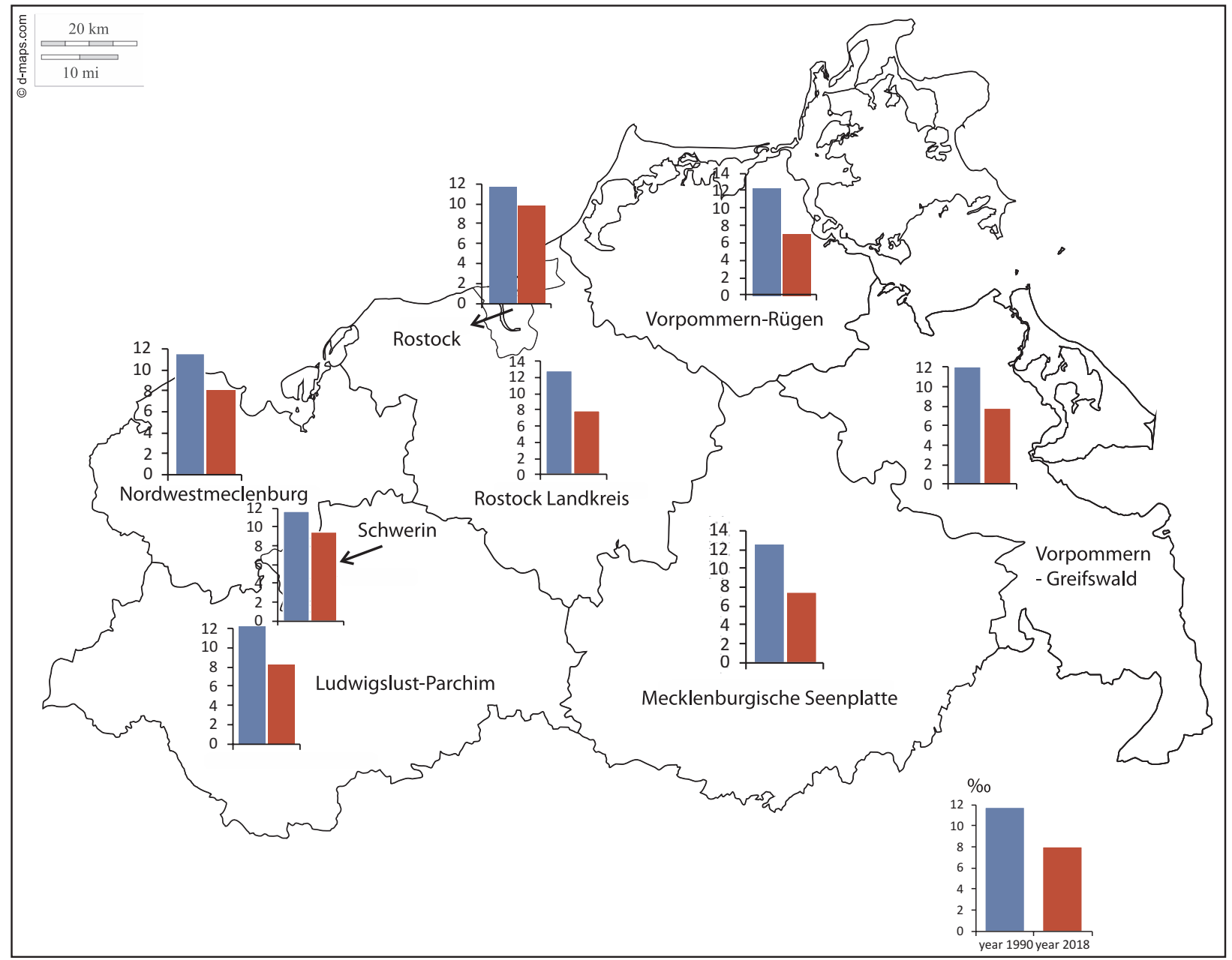

Fig. 4. Live births per 1,000 population in the federal state of Mecklenburg-Vorpommern

Source: Own study based on www.statistik-mv.de

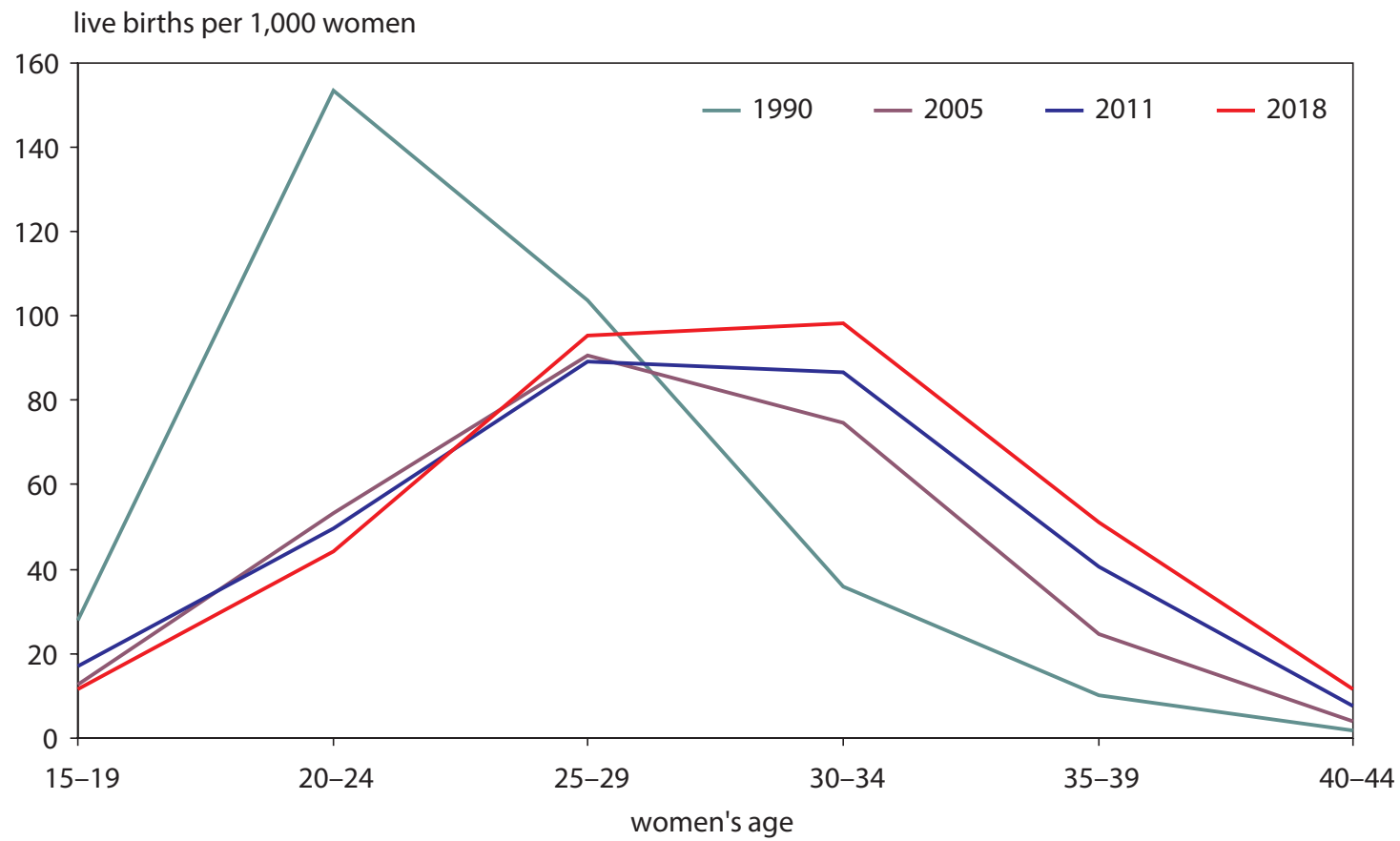

Fig. 5. Distribution of female fertility in Mecklenburg-Vorpommern Source: Own study based on www.statistik-mv.de 
$1998-2001$ to $13.6 \%$ in 2018 . Given the basic statistical characteristics of deaths in Mecklenburg-Vorpommern, they are more favorable for Germany (Fig. 3 ). Both the interquartile range, the median value and the maximum value are more optimistic. Assuming that the total death rate depends on the intensity of the phenomenon in individual age groups and on the age structure of the population, an analysis of changes in mortality in individual cohorts was made. As follows from research, partial death rates in most age groups significantly decreased. As a result, the increasing average life expectancy and a growth in the number of people in the oldest age groups have contributed to the deepening of aging processes in Mecklenburg-Vorpommern (Kemper, Kurek, 2006). This was confirmed by the calculated demographic aging indices $\left(I_{D A}\right)$ for several critical moments important from the point of view of the population situation:

- 1990-2000 the first decade of Wendeknick in Germany $I_{D A}$ amounted to 20.3;

- 2004-2018 accession of most Central and Eastern European countries to the European Union, $\mathrm{I}_{\mathrm{DA}}$ amounted to 4.1 ;

- 2011-2018 opening of the German labor market and immigration from Asia and Africa, $\mathrm{I}_{\mathrm{DA}}$ amounted to 1.5;

- 1990-2018 after almost 30 years of Wendeknick $\mathrm{I}_{\mathrm{DA}}$ amounted to 23.1 .
Basically, the conducted analyses confirmed the progressive process of demographic aging of population in 1990-2018; however, with opening of the German labor market and a strong immigration stream of population from Asia and Africa, there was temporary rejuvenation of the German society. An in-depth analysis of the number of births and deaths allowed assessing the size of natural increase in the population of Mecklenburg-Vorpommern (Fig. 3). During the period under the study, a downward trend with progressive natural decrease was clearly visible. The spatial arrangement of the rate of natural increase, similarly to the rate of parity, can be compared to a centrifugal system with a barrier in the form of a border with Poland. With increasing distance from the border towards the regional center, the balance of natural movement takes values that are more favorable.

\section{Migration movement}

Migrations, next to natural increase, are a fundamental component of the population growth. They are also an important factor changing the number of inhabitants, its structure and the demographic potential of regions. In 1990-2018, the role of migration in the demographic development of the federal state of Mecklenburg-Vorpommern was particularly important (Fig. 6).

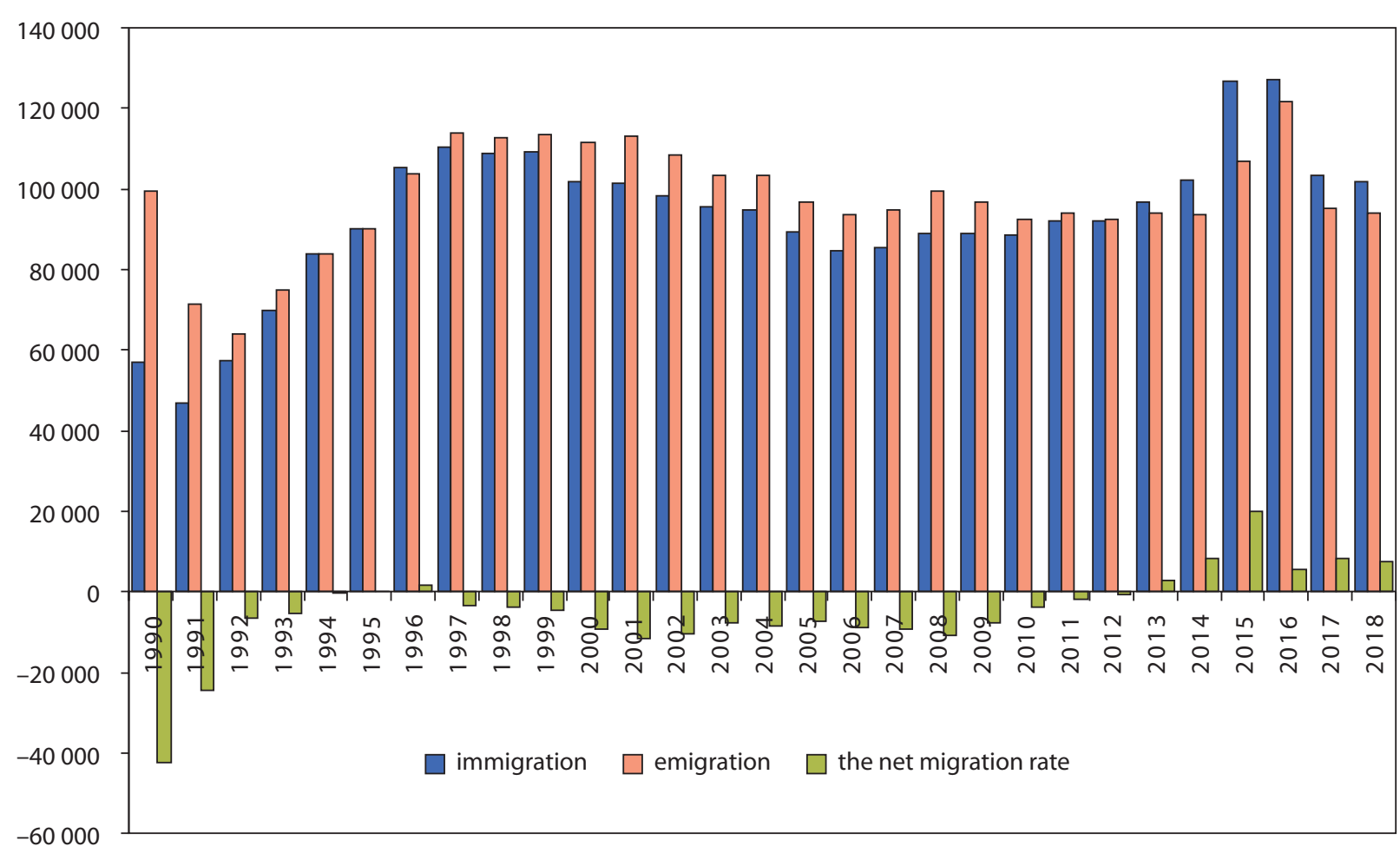

Fig. 6. Inflow, total migration outflow and net migration in Mecklenburg-Vorpommern in 1990-2018 [in persons] Source: Own study based on www.statistik-mv.de 
In the structure of migration inflow, internal migrations dominated, on average constituting $63.4 \%$ of the total inflow. In the first two years after the reunification of Germany, an average of 18,700 persons came from the federal states and from abroad every year, of whom $1 / 5$ were foreigners. Until the end of 2010, the inflow remained stable at around 30,000 persons per year, while 2014-2018 the average increased to 48,600 persons a year, of whom $1 / 2$ of the inflow were foreigners. The national structure of foreigners in geographical terms is extremely interesting. In 2004, immigrants mainly from the European Union $(70.3 \%$ of the total) came to MecklenburgVorpommern. After the accession of new countries to the European Union in 2004, Germany became an important destination for Poles, who were the most numerous group among foreigners ( $1 / 4$ of all foreigners in 2004 and $1 / 3$ in 2018). It should be emphasized here that this is largely a result of the border location of the land. Earlier, often pre-accession contacts of Poles, seasonal labor migrations to Germany, and above all an attractive offer of flats to buy and a system of German social benefits encouraged Poles to settle in Germany permanently. A slightly different migration inflow occurred in 2013-2018, when an average of 17,500 people came to Mecklenburg-Vorpommern every year. The ensuing situation meant accepting a record number of immigrants and refugees from Asian countries (Syria, Saudi Arabia), 34,300 people in total in 20132018 and 5,400 people from Africa (Egypt, Ethiopia). People from the other 15 federal states of Germany made up an additional stream of immigration inflow with an upward trend. As expected, more than half of it (52.7\% of total inflow) came from neighboring old and new German federal states. These were the following states: Schleswig-Holstein (15.0\% of total inflow), Brandenburg (13.5\%), Lower Saxony (12.2\%) and Berlin (12.0\%).

In turn, the migration outflow in the state of Mecklenburg-Vorpommern showed specific features (Fig. 6). First, the outflow structure in the first three years after the collapse of the GDR was dominated by the outflow outside the borders of the state and the whole country. Proportions for the share of internal migrations were at the level of $48.1 \%$, with external ones being $51.8 \%$. In just three years, 139,600 persons departed outside the state borders. Political and economic changes, the so-called Wendeknick, caused unprecedented migrations of people to the western federal states (Grundmann, 1998). In 1991, the largest number of residents of MecklenburgVorpommern moved to the neighboring states but which before 1990 were separated by the state border between the GDR and West Germany. Old federal states which took in the largest number of emigrants were Schleswig Holstein (19.8\% of the total outflow outside the state), Lower Saxony (18.07\%) and North Rhine-Westphalia (11.4\%). However, considering the intra-regional diversity of Mecklenburg-Vorpommern, the areas with the largest outflow outside the state borders were districts located in the border zone with Poland. For example, there were 2,600 persons less in the former Uecker-Randow district, 2,800 persons in the Ostvorpommern district, and 2,600 persons in Nordvorpommern; the further from the border, the more decreasing the outflow stream. Undoubtedly, from a demographic point of view, the age of people leaving Mecklenburg-Vorpommern remained a big threat. As results from the analysis, in consistence with the principle of migration selectivity, young people dominated in the structure of leaving persons (Jażewicz, 2008). The subpopulation aged $18-30$ constituted as many as $1 / 2$ of emigrants and was dominated by women. Imbalance in the population of men and women at the age of the highest reproductive activity will have a negative impact on the population size of the studied state and its reproduction in the future.

In the following years 1993-2018, the population outflow levelled off at 102,300 a year, of which $62.3 \%$ was the average internal migration outflow, $31.1 \%$ outflow to other German federal states and $6.6 \%$ outflow abroad. As regards geographical flows between the federal states, they were consolidated, and they are still the highest to the old states (Pastuszka, 2019). Foreign emigration played a relatively smaller role in shaping the population than foreign immigration. In 1990-2018, a total of 172,000 persons moved abroad. This was dominated by moving to the European Union countries, mainly to Poland and Romania. In the flow system between the districts of Mecklenburg-Vorpommern, border districts still have the highest migration outflow outside the land borders.

When assessing the volume of net migration in Mecklenburg-Vorpommern during 1990-2012, there is a clear advantage of migration outflow over inflow (Fig. 6). Especially in the first years of Wendeknick, there was a very high negative net migration, which took extreme values of 42,300 persons in 1990. In later years, net migration decreased, although it remained a component negatively affecting the population number. In 1995-1996, net migration was ephemerally positive; however, the years 2013-2018 had a significant impact on the demographic development of the state, when net migration was positive due to the inflow of immigrants from Asia and Africa. 


\section{Summary}

The conducted research clearly confirmed that the current demographic situation in the state of Mecklenburg-Vorpommern is a consequence of the so-called Wendeknick. Political and economic transformation after reunification of Germany caused profound changes in the residents' reproductive behavior and contributed to a change in their migration attitudes. In addition to the process of German reunification, the situation was largely affected by external factors, especially by processes of accession of Central and Eastern European countries to the European Union in 2004, and later in 2011 by the opening of the German labor market. Furthermore, the unusually high wave of immigration inflow from Asia and Africa in 2013-2018 influenced changes in the demographic situation of Mecklenburg-Vorpommern.

Research shows that the analyzed region is an area of a depopulation character, where 0.3 million inhabitants left over the past 28 years. On the one hand, it should be noted that it was mainly the natural decrease that contributed to the decline in population, which was caused both by demographic factors in the form of a decrease in fertility levels, but also by non-geographical factors of an economic character. Despite the high public financial transfers to the new federal states of Germany as part of the integration of both German states, the standard and quality of life differed from the old federal states, which remained a classic push factor to move outside the state. Circular displacements related to work and the search for better living conditions meant that in the first years after the integration of Germany about 46,000 residents a year left for the neighboring states formerly within the borders of West Germany. Increased migration drainage in connection with natural decrease resulted in general weakening of the demographic potential of Mecklenburg-Vorpommern. Consequently, accompanying processes related to demographic aging of the population, impoverishment of the human capital, a problem with simple replacement of generations or deformation of the demographic structure of the population were revealed. The immigration inflow from EU countries and from outside the European continent has become a kind of relief of the unfavorable demographic situation in Mecklenburg-Vorpommern. Women coming from abroad proved to be biologically resilient and highly fertile, especially at the age of increased parity (20-29 years old), which was also supported by their favorable age structure. It seems, however, that such a situation has an intermediate impact, because today there is a clearly weakening tendency of the immigration inflow. According to demographic forecasts prepared by the Federal Statistical Office, the population number in Mecklenburg-Vorpommern will drop by 0.2 million by 2050 and will amount to 1.4 million.

However, in the federal state itself, there is evident polarization in the distribution of human resources and in the processes of concentration and depopulation. Location close to the Polish-German border remains the causative factor. The distribution of population and demographic processes are centrifugally directed from border areas of a peripheral character towards the state capital - Schwerin. The closer to the border, the weaker the demographic potential. Partially depopulated western borderland has become settled by Polish citizens who initially only commuted to work and eventually permanently settled down by buying at preferential prices property abandoned by the Germans.

To sum up, the state of Mecklenburg-Vorpommern is marked by a stigma of belonging to the East German states, which, compared to the old federal states, remain developmentally distanced in terms of demographics. Certainly, this is a result of looking for a more attractive place to live and work.

\section{References}

Akturk S., 2016, Post-imperial democracies and new projects of nationhood in Eurasia: transforming the nation through migration in Russia and Turkey, Journal of Ethnic and Migration Studies, 43(7), 1101-1120. doi:10.1080/136 9183x.2016.1246177

Basten S., Sobotka T., Zeman K., 2013, Future Fertility in Low Fertility Countries, Vienna Institute of Demography Working Papers, 5/2013, https://www.oeaw.ac.at/fileadmin/ subsites/Institute/VID/PDF/Publications/Working_Papers/WP2013_05.pdf (accessed 23.11.2019).

Bogaarts J., Sobotka T., 2012, A Demographic Explanation for the Recent Rise in European Fertility, Population and Development Review, 38(1), 83-120. doi:org/10.1111/j.17284457.2012.00473.x

Buchman L., 2009, Migration in Mecklenburg, Pommern und Vorpommern im 19. und 20. Jahrhundert, Empirische Analysen zur Bevölkerungsentwicklung (Eng. Migration in Mecklenburg, Pomerania and Vorpommern in the 19th and 20th centuries. Empirical analysis of the population development), der Universität Rostock, Rostock.

Chojnicki Z., 1999, Podstawy metodologiczne i teoretyczne geografii (Eng. Methodological and theoretical bases of geography), Bogucki Wydawnictwo Naukowe, Poznań.

Ciok S., Dołzbłasz S., Leśniak M., Raczyk A., 2008, Polska-Niemcy. Współpraca i konkurencja na pograniczu (Eng. PolandGermany. Cooperation and competition on the border), Wydawnictwo Uniwersytetu Wrocławskiego, Wrocław. 
Goldstein J.R., Kreyenfeld M., 2011, Has East Germany Overtaken West Germany? Recent Trends in Order Specific Fertility, Population and Development Review, 37(3), 453-472. doi: org/10.1111/j.1728-4457.2011.00430.x

Goldstein J.R., Sobotka T., Jasilioniene A., 2009, The End of "Lowest Low" Fertility?, Population and Development Review, 35(4), 663-699. doi: org/10.1111/j.17284457.2009.00304.x

Grundmann S., 1998, Bevölkersungsentwicklung In Ostdeutschland, Demographische Strukturen und räumliche Wandlungsprozesse auf dem Gebiet der neuen Bundesländer (Eng. Population development in East Germany, demographic structures and processes of spatial change in the new federal states), Leske+ Budrich, Opladen.

Grykień S., 2004, Przekształcenia w rolnictwie Europy Środkowo-Wschodniej ze szczególnym uwzględnieniem nowych krajów związkowych Niemiec, Polski i Ukrainy (Eng. Transformations in agriculture in Central and Eastern Europe, with particular emphasis on the new federal states of Germany, Poland and Ukraine), Wydawnictwo Uniwersytetu Wrocławskiego, Wrocław.

Jażewicz l., 2008, Problemy rozwoju regionalnego na pograniczu polsko - niemieckim na przykładzie woj. zachodniopomorskiego i Meklemburgii - Pomorze Przednie (Eng. Problems of regional development on the PolishGerman border based on the example of the West-Pomeranian Voivodeship and Mecklenburg-Vorpommern), [in:] S. Dołzbłasz, A. Raczyk (eds.), Przekształcenia regionalnych struktur funkcjonalno-przestrzennych. Europa bez granic - nowa jakość przestrzeni, (Eng. Transformation of regional functional-spatial structures. Europe without borders - a new quality of space), Instytut Geografii i Rozwoju Regionalnego Uniwersytetu Wrocławskiego, Wrocław, 75-82.

Jezierska-Thöle A., 2016, Zmiany w zasobach i jakości kapitału ludzkiego na obszarach wiejskich Polski i Wschodnich Niemiec (Eng. Changes in the resources and quality of human capital in rural areas of Poland and East Germany), Studia Obszarów Wiejskich, 41, 167-183. doi: org/10.7163/ SOW.41.11

Jezierska-Thöle A., 2018, Rozwój obszarów wiejskich Polski Północnej i Zachodniej oraz Niemiec Wschodnich, (Eng. The development of rural areas in Northern and Western Poland and East Germany), Wydawnictwo Uniwersytetu Mikołaja Kopernika, Toruń.

Kemper F., Kurek S., 2006, Population ageing in Germany and Poland: a comparison of regional developments in the 1990s, Collection Arbeitsberichte, Publisher Geographisches Institut, Humboldt-Universität zu Berlin, Berlin.

Kurek S., 2012, Przemiany demograficzne w Polsce w świetle teorii drugiego przejścia demograficznego w ujęciu przestrzennym (Demographic changes in Poland based on the second demographic transition theory from spatial view), [in:] A. Rączaszek (ed.), Demograficzne uwarunkowania rozwoju społecznego (Eng. Demographic determinants of social development), Wydawnictwo Uniwersytetu Ekonomicznego, Katowice, 217-230.

Lesthaeghe R., 2010, The unfolding story of the second demographic transition, Population and Develop- ment Review, 36(2), 211-251. doi: org/10.1111/j.17284457.2010.00328.x

Lesthaeghe R., 2014, The second demographic transition: A concise overview of its development, PNAS, 111(51),18112-18115. doi: org/10.1073/pnas.1420441111 Magdalenić I., 2016, Uticaj bračnosti na fertilitet u Srbiji i Evropskoj Uniji (The influence of marital status on fertility in Serbia and the European Union), Demografija, 13, 175190.

Michalski T., 2012, Przemiany w umieralności w Europie Środkowej i Środkowo-Wschodniej w okresie transformacji (Eng. Changes in mortality in Central and Central-Eastern Europe during the transformation), Wydawnictwo "Bernardinum", Pelplin.

Milewski N., 2010, Fertility of Immigrants: A Two-Generational Approach in Germany, series: Demographic Research Monographs, 6, Springer-Verlag, Berlin - Heidelberg, www.demogr.mpg.de/books/drm/006/ (accessed 28 December 2019).

Okólski M., 2010, Demographic Challenges of Europe and Poland, Studia Socjologiczne, 4(199), 37-78.

Osiewalska B., 2018, Partners' empowerment and fertility in ten European countries, Demographic Research, 38, 14951534. doi: 10.4054/DemRes.2018.38.49

Pastuszka S., 2016, Polityka rozwoju wschodnich Niemiec cele, narzędzia, efekty (Eng. Eastern Germany development policy - goals, tools, effects). Optimum. Studia Ekonomiczne, 6(84), 56-75. doi: 10.15290/ose.2016.06.84.05

Pastuszka S., 2019, Potencjał demograficzny landów Niemiec Wschodnich i województw Polski wschodniej, (Eng. Demographic potential of the states of East Germany and voivodships in Eastern), Studia Prawniczo-Ekonomiczne, 60, 253-272. doi: 10.26485/SPE/2019/110/14

Satistisches Bundesamt, www.destatis.de (accessed 5 January 2020).

Šprocha B., Šídlo L., Burcin B., 2015, Úroveň úmrtnosti na Slovensku a v Česku v európskom pohlade (Eng. Mortality in the Czech Republic and in the Slovak Republic and Compared to Europe), Geografický časopis, 67(1), 25-43.

Statistisches Amt Mecklenburg-Vorpommern, www.statistikmv.de (accessed 3 January 2020).

Van de Kaa D.J., 1987, Europe's second demographic transition, Population Bulletin, 42(1), 1-59.

van Nimwegen N., van der Erf R., 2010, Europe at the Crossroads: Demographic Challenges and International Migration, Journal of Ethnic and Migration Studies, 36(9), 13591379. doi: 10.1080/1369183X.2010.515132 